\title{
11. The Western Legal Response to Sorcery in Colonial Papua New Guinea
}

\author{
Mel Keenan
}

\section{Introduction}

In July 2013 the national parliament of Papua New Guinea (PNG) repealed that country's Sorcery Act, as one prong of a strategy aimed at bringing an end to the appalling sorcery-related violence throughout the country. Dating back to 1971, some years before independence, the Act's roots lie in the period of PNG's torpor as an Australian colony. This chapter takes the long historical view of the notoriously a-historical common law, in order to provide some examination of the response of colonial administrators working within an imported common law framework to crimes arising from the pervasive belief in sorcery throughout PNG. ${ }^{1}$

The Western legal 'response' to sorcery denotes the entire panoply of modern law making and law enforcing in colonial PNG: policymaking, the legislative process, law enforcement and judicial decision-making. At its core is how did the Western criminal justice system deal with the genuinely held belief that sorcerers could from afar be the cause of a wide range of results - including consequent self-protective or retaliatory violence - all of which were potentially punishable under the colonists' law? This requires the consideration in an introductory way of the common law's historical response to sorcery or witchcraft allegations, and the manner in which two leading colonial administrators in PNG, Sir William MacGregor and Sir Hubert Murray, used the common law to deal with contemporary sorcery-related crime. The failure to acknowledge that history, coupled with assumptions about the universal applicability of the common law, imposed on PNG a legal regime which at the one time gave statutory recognition to sorcery practices, while signally failing to provide effective protection from its aftermath. Arguably, this 'worst of both worlds' result exacerbated the recent upsurge in sorcery-related violence in PNG, and led to the Sorcery Act's repeal.

\footnotetext{
1 The material in this chapter is the result of research undertaken towards a thesis of the same title for the degree of Doctor of Philosophy in law from Monash University, Melbourne, under the supervision of Guy Powles and Melissa Castan.
} 
An immediate issue is the intertwining of the processes of colonialism with that of the introduction of Western law to PNG: of course the latter could not have occurred without the former. However, I argue that theories of colonialism based on the proposition that the demands of capitalism necessarily entailed imperialist expansion, as capitalists in the metropolis sought increased resources and wider markets (see, for example, Blaut 1989) do not sufficiently explain the colonisation of PNG - although the South Pacific certainly was divided up as part of the imperial scramble of the late nineteenth century. Rather, the creation by the British of the rather odd entity, the Western Pacific High Commission, and the eventual extension of British 'Protection' over south-east New Guinea is better characterised as a policy of extending British sovereignty over her own subjects, inspired to some extent by the criminal activities of Australians - especially Queenslanders - kidnapping Pacific islanders to work on sugar plantations. ${ }^{2}$ To this extent, the common law actually 'arrived' in PNG before any structures of colonial administration.

\section{The first grandchild of the British Empire}

Occurring in a colony of first Great Britain and then Australia, sorcery in PNG was dealt with as a criminal offence under colonial ordinances and regulations. Colonial administrators did make some efforts to establish how sorcery operated to maintain social equilibrium within tribal groups. Thus, Sir Hubert Murray in the early twentieth century referred to Bronislaw Malinowski's pioneering anthropological work among the Trobriand Islanders which highlighted the 'qualitative difference between the then-prevailing concept of law ... and the native bilateral view of law as deserving obedience as one part of a larger, personally beneficial chain of binding relationships' (Donovan 2008:73-5).

I suggest that one lens through which the conduct of colonial administration might be viewed is the unusual way in which PNG became part of the British Empire. Supposedly concerned by the increasing German presence in the southwest Pacific, on 4 April 1883 Queensland Premier Thomas McIlwraith ordered the police magistrate on Thursday Island to formally annex New Guinea and adjacent islands in the name of the British government. The Colonial Office was unamused, and this unilateral action was disallowed on the basis that a colonial government had no authority to annex other colonies. However, when Imperial

\footnotetext{
2 The Western Pacific Order in Council of 1877 established the High Commission for the Western Pacific and gave the High Commissioner's Court jurisdiction over British subjects in the area. Article 24 of the order gave the high commissioner power to make regulations for the government of British subjects or 'for securing the maintenance (as far as regards the conduct of British subjects) of friendly relations between British subjects and those authorities and persons subject to them' (Angelo et al. 1989:31).
} 
Germany claimed the north-eastern part of New Guinea as Kaiser-Wilhelmsland in the following year, the Union Jack was quickly hoisted in Port Moresby over the new crown colony of British New Guinea.

Subsequent to this brief flurry of activity, PNG held little interest for the vast majority of Australians, even after British New Guinea became the Australian Territory of Papua in 1906. This meant that administrators on the ground had considerable latitude in defining 'native policy'. This was particularly the case with Sir Hubert Murray, administrator of Papua from 1906 until his death in 1940. A trained lawyer, Murray was also chief judicial officer of the territory. However, despite the fact that he took pains to employ contemporary anthropological theories — especially the functionalism of Malinowski and his disciples - Murray was ultimately a public servant who wanted to maintain order, and the paternalistic practices introduced by him that had been groundbreaking at the time of World War I were woefully obsolete by the time of World War II.

After World War II, and under increasing international scrutiny, the real locus of power shifted from the administrator in Port Moresby to the minister in Canberra, particularly the exacting Paul Hasluck. As the British Empire was 'handed back' one territory at a time, Australia's lingering presence in PNG became ever more anachronistic, leading the Whitlam Labor government to thrust independence on the territory in 1975, the last act of colonial arrogance. ${ }^{3}$

Throughout this period the common law played a vital role in the 'pacification' and 'civilisation' of Papua New Guineans. Other than headhunting and cannibalism, sorcery practices were perhaps the most abhorrent to the colonisers' sensibilities - easily forgetting that only a few hundred years before, the common law in England and its American colonies had dealt with almost identical issues. As a question of public order, sorcery was prohibited under some of the earliest native regulations put in place by administrator Sir William MacGregor in the 1890s. ${ }^{4}$ Nonetheless, even if the colonisers were unaware of regional varieties in belief, the ubiquity of sorcery practices meant that judicial officers had to take it into consideration in sentencing, and that a belief in its practice could be used as a provocation defence. The continuing strength and extent of the belief in the efficacy of sorcery was attested to by the passage of the Sorcery Act in 1971, shortly before independence, and the series of reports produced by the

\footnotetext{
3 See Nelson (1982:211). On the phases of Australian policy, see Hudson (1974:x) and Legge (1956).

4 MacGregor's biographer, the historian Roger Joyce, felt that MacGregor could have shown more sympathy and understanding towards native society, by reference perhaps to the anthropological work being undertaken by Charles Seligman in the Torres Strait in the 1890s (Joyce 1971:143). However, given that the Cambridge University expedition of which Seligman was a part didn't arrive on Thursday Island until April 1898, this is unfair to MacGregor.
} 
Talking it Through

PNG Law Reform Commission in the late 1970s. ${ }^{5}$ Despite this official response - or perhaps partly because of it - sorcery-related crime remains a seemingly intractable problem in contemporary PNG.

\section{The historical response of the common law}

In dealing with criminal sanctions for the practice of sorcery, colonial legal authorities in PNG operated within a framework which had been applied to similarly alleged practices over a period of hundreds of years, as common law practice evolved. This evolution had taken place with a background of legislation in Christian Europe, which criminalised the practice of witchcraft, especially that of maleficium, or the deliberate inflicting of harm on persons and property. In the historical context, leading British anthropologist Keith Thomas (2004:48) restricted the term 'witchcraft' to mean:

the employment (or presumed employment) of some supernatural means of doing harm to other people in a way that was generally disapproved of by the mass of society.

As will be seen, it was this concept of inflicting harm that was at the core of the common law response to alleged witchcraft.

Ultimately, belief in the Christian duty to eradicate witches within Europe was based on passages in the Old Testament, which, it has been argued, were in turn based on the earlier Laws of Hammurabi, dating back to before $1750 \mathrm{BC}$ (Wright 2009:200-201). So there is a considerable lineage here. Still, despite these biblical injunctions, the early church paid little attention to the question of witchcraft, with St Augustine in the fifth century declaring that witchcraft and satanic power were impossible, as God alone had the power to suspend the laws of nature. However, church attitudes hardened in the wake of the popularity and strength of medieval heresies, so that by 1484 a Papal Bull recognised the existence of witches, and the ensuing Inquisitors' handbook, Malleus Maleficarum - the Hammer of the Witches - became the textbook for European witch trials for centuries. It was the Malleus that imprinted on the popular European imagination the image of the witch not only as the village practitioner of malevolent magic, but as the cohort of the devil flying through the night to worship Satan at Sabbaths.

The roots of the English legislative response to witchcraft lie in the ferment of the Reformation: whereas the medieval Catholic Church had provided 'magic'

5 These were Sorcery, Occasional Paper No. 4, October 1977; Sorcery among the Tolai People, Occasional Paper No. 8, April 1978; Sorcery among the East Sepiks, Occasional Paper No. 10, October 1978; and The Effects of Sorcery in Kilenge, West New Britain Province, Occasional Paper No. 11, August 1979. 
of its own in the form of ritual blessings to ward off evil, the Reformation did away with these unbiblical practices. It is unsurprising then that the first Act criminalising witchcraft came in the course of the Henrician Reformation. The Witchcraft Act of 1542 defined witchcraft as a capital offence, and forbade:

the use, devise practice or exercise ... of any Invocations or conjurations of Spirits witchcrafts enchantments or sorceries to the intent to find money or treasure or to waste consume or destroy any person in his bodily members, or to provoke any person to unlawful love, or for any other unlawful intent or purpose.

The wording clearly shows that the Act was directed at maleficium, encompassing allegations such as causing people or livestock to sicken and die, destroying crops by summoning bad weather, and 'turning' butter or spoiling food. All of these were of vital import to small agrarian communities, living close to subsistence level, particularly in times of social upheaval. They also denote the intimate personal and economic relationships which often characterised accused and accuser in English witchcraft trials: women were disproportionately accused of witchcraft, and none more so than socially dislocated widows and spinsters whose poverty made them a drain on the welfare of their neighbours and the sparse resources of their communities. ${ }^{6}$

In 1603, the Stuart James VI came to the English throne from a Scottish realm in which both the practice of witchcraft and consulting with witches were capital offences. The ensuing Witchcraft Act of 1604 no longer focused on the malicious intent of the accused, but on the pact with evil spirits and devils, a felony punishable by death. As the witchcraft legislation did not include any specific ways of proving the maleficium, courts relied upon contemporary criminal procedure. Witchcraft was known as a crimen exceptum, or a category of grave offence which, of its very nature, was not amenable to finding evidence. It was therefore to be expected that its prosecution would not be possible with reference to existing principles of proof, normal standards of interrogation or court procedure (Larner 2002:205).

Relying on the Jacobean Act, in Essex during the English Civil War of the 1640s, puritan 'witchfinders' Matthew Hopkins and John Sterne used evidence-finding practices which in the twenty-first century might be described as 'enhanced interrogation techniques', such as sleep deprivation, to purportedly discern the 'marks' of a witch as a preliminary to trial. In doing so, in only 14 months they led to the arrest of nearly 300 men and women and effectively caused the deaths of 230, either by way of judicial execution, or in crowded local prisons in which disease was rife (Gaskill 2005). However, the Essex witch hunts were

6 Throughout England, issues of community responsibility, gender roles and poverty 'combined explosively with popular beliefs about the supernatural to create a tragedy' (Timmons 2006:304). 
an exception to the general rule in England of findings of innocence due to a lack of credible evidence, and they can be attributed largely to the unique and explosive combination of social upheaval and the strength of local Puritanism, a combination which would again prove to be deadly in the Salem witch trials of colonial New England some 50 years later (Hoffer 1997:81).

However, by making witchcraft a felony, the witchcraft Acts had removed it from the remit of the ecclesiastical courts and given it to those of the common law; placing witchcraft trials in the hands of the common lawyers actually contributed to the professionalisation of roles of judge and prosecutor, thereby delineating the common lawyers as experts in assessing the evidence of witchcraft. The very success of the Essex witchfinders' reliance upon 'evidence' of the accused as witches contained within it the seeds of the destruction of the witchcraft trial. In stressing the reality of the discernible signs of witchcraft, the witchfinders effectively set the evidentiary boundaries for subsequent prosecutions, and it became necessary to show clear proof of a demonic pact. By the end of the seventeenth century, this 'increasingly taxing exercise in persuasion and proof' had become impossible. Accordingly, all of the 39 witchcraft indictments filed at the English Home Circuit - the populous counties of Essex, Hertfordshire, Kent, Surrey and Sussex — between 1660 and 1701 resulted in acquittals (Gaskill 2008:61).

The final English Witchcraft Act of 1736 demonstrated the change in mindset that characterised the early eighteenth century. Although there had been a decline in indictments prior to 1736, this was due to the fact that, as trials became somewhat of a legal embarrassment, judges increasingly dismissed them outright or dealt with them informally, so that the Jacobean Act was a dead letter long before its repeal (Davies 1999:8). Rather than punishing supposed maleficium or pacts with the devil, the 1736 Act aimed to prevent and punish 'any Pretences' to witchcraft, pursuant to which 'ignorant Persons are frequently deluded and defrauded', so that it was an offence to:

pretend to exercise or use any kind of Witchcraft, Sorcery, Inchantment, or Conjuration, or undertake to tell Fortunes, or pretend, from his or her Skill or Knowledge in any occult or crafty Science, to discover where or in what manner any Goods or Chattels, supposed to have been stolen or lost, may be found.

The witch trial therefore played an important role in the construction of legal modernity. Between the Acts of 1542 and 1736, common lawyers forced those who alleged the statutory crime of witchcraft to prove the unprovable by way of inductive reasoning based on credible evidence. In relying on evidence of witch marks or a satanic compact that was to be admitted in court, the witchfinders' attempt to prove the irrational by way of rationality doomed the very notion of 
a witch trial. Once this process started, its momentum could not be stopped, and ultimately the law of evidence not only confronted witchcraft, but effectively vanquished it; as the founder of Methodism John Wesley lamented, the nonbelievers had 'hooted witchcraft out of the world' (Trevor-Roper 1967:96).

The reason for this trip through the centuries - or millennia if we go back to Hammurabi - has been to show that in England the common law vanquished the unprovable crime of witchcraft by the application of logic and the development of rules of evidence. However, it was a process that took many hundreds of years, and which undoubtedly was hastened by a decline of religious intensity among the educated classes. Nonetheless, if colonial administrators had been prepared to acknowledge this incremental process, they may have brought to PNG a more nuanced approach to applying the common law to sorcery beliefs.

\section{The colonial response}

The tone throughout the colonial period for dealing with crimes committed by Papua New Guineans had been set by perhaps the first application of British law when, in 1884, the special commissioner for what was then a British Protectorate, Sir Peter Scratchley, refused to sentence to death a payback murderer who had voluntarily turned himself in and offered compensation payment. Scratchley did not sentence him to death, because to do so in the wake of his voluntary submission would have been revenge rather than justice. Instead, he recommended to the Colonial Office that the culprit be detained at Port Moresby for 10-12 months and then returned to his home island.

Scratchley was not to oversee the establishment of the crown colony, as he contracted malaria and died at sea en route to Australia in December 1885. John Douglas - erstwhile premier of Queensland - then acted in the position of administrator until 4 September 1888, when British New Guinea was finally annexed as a crown colony and Dr William Macgregor, government medical officer for Fiji and deputy commissioner for the western Pacific, was appointed administrator.

As the first administrator of British New Guinea, MacGregor was adamant that a paternal form of justice was the most suitable for people 'in the act of stepping out of savagery and barbarism into civilisation' (Joyce 1971:120). Sorcery practices were the ubiquitous evil, as MacGregor acknowledged the pre-eminent belief among Papua New Guineans that death was caused by sorcery rather than by natural causes, a belief which led to a large number of murders or acts of violence, in vengeance against suspected sorcerers: indeed, he felt that the only commonality among the myriad indigenous tribes was this belief in sorcery. In the 1890s, MacGregor's chief judicial officer noted that where the motive for 
a murder led it to be justified among the natives — such as in sorcery-related crimes - it should not stop the court from reaching a verdict of guilty, but it would be reasonable for it to lessen the sentence. This remained the leitmotiv of criminal practice in PNG - criminal trials were conducted with the full array of royal justice; guilty verdicts sternly pronounced, but sentences a fraction of those that 'civilised Europeans' would have received.

MacGregor thus set about to cut the belief in sorcery at its roots, using the law as one of his main weapons. The Colonial Office had instructed him to introduce a judicial system that was as summary and simple as was possible, and the laws of Queensland were adopted for British New Guinea 'insofar as the same are applicable to the circumstances of the Possession and not repugnant to any provision in its constitution'. ${ }^{7}$ They were soon complemented with a separate Native Affairs Ordinance 1889 for the colony written in simple English and translated into Motuan, the language of the people of the Port Moresby district. Although the Letters Patent establishing the colony required the advice of nominated executive and legislative councils, the ideas for most ordinances were MacGregor's own, and his particular solution to combat sorcery practices lay in English, Fijian and West Indian precedents whereby the 'pretence' of holding such powers was made an offence (Joyce 1971:188). Thus, clause 80(1) of the Native Regulation Board Ordinance 1893 provided:

Sorcery is only deceit, but the lies of the Sorcerer frighten many people and cause great trouble, therefore the Sorcerer must be punished. ${ }^{8}$

In 1902 British New Guinea became the Australian Territory of Papua, and the 1893 ordinance was continued by the Native Regulation Act 1908 of the Papuan administration of Sir Hubert Murray and remained largely in force until independence. ${ }^{9}$ Murray's policies in the twentieth century can be viewed as a continuation of those of MacGregor - a 'benevolent tradition' of European development tempered by protective safeguards for the Papuans (Elkin 1940:28; Legge 1956:133-4). However, he was the first to realise that determining the appropriate legal response to an impugned custom required a thought-out policy, rather than simply responding to matters as they arose. Murray also

\footnotetext{
7 In June 1888 the Secretary of State for the Colonies, Lord Knutsford, had recommended extending Queensland law to Papua, but John Douglas disagreed, suggesting instead that a 'slight amplification and modification of the Ten Commandments would really be more suitable to the existing circumstances' (Sinclair 2009:50).

8 Eventually the Queensland Criminal Code of 1899 was adopted in Papua in 1903 and in New Guinea in 1921: ironically, even the practice of dissecting a body to ascertain whether the person had died from sorcery constituted an offence of interfering with a dead body under Section 236 of the code.

9 Section 6(1) of the Papua Act 1905 (Commonwealth) stipulated that laws previously in force were to continue to operate until other provisions be made.
} 
had the benefit of the legal anthropology of Bronislaw Malinowski, whose work among the Trobriand Islanders added momentum to the doctrine that law is social behaviour and not logical abstraction (Hoebel 1946:851).

There is a considerable corpus of material on Murray's reliance on anthropology, with some questioning whether he simply used it to bolster his own opinions and give an additional veneer of intellectual respectability to his administration. ${ }^{10}$ Nonetheless, what is unarguable is that when the demands of anthropology and those of public order conflicted, public order always took precedence. Therefore, the determination of whether or not a traditional custom should be allowed to continue was always predicated upon to what extent it was viewed by the coloniser as congenial to the progress of the colonial project in Papua. ${ }^{11}$ If, as Murray described it, the custom led to disorder, it had to be suppressed without equivocation. As the practice of sorcery was the exemplar of a custom that led to disorder, he rejected outright anthropological arguments for a policy response based on the centrality of sorcery beliefs to Papua New Guinean society:

Take for instance the case of sorcery. We punish sorcery with six months' imprisonment, but only sorcery which is practised with intent to kill or injure — 'black magic' in short; and we punish it because it creates disorder by encouraging retaliatory murders and other acts of violence on the part of the relations of the man who has been bewitched. (Murray 1929a:14)

Murray suggested that Papua New Guineans felt that the statutory punishment was too light to be effective, but countered that care ought to be exercised in imposing a heavy penalty for what was 'really an imaginary offence' (ibid.), and that it should instead be thought of as a form of deceit, as set out in the relevant regulation. Nonetheless, he conceded that the sorcerer believed in his power as unreservedly as did his victim, and his writings show that his abhorrence of sorcery practices was not solely due to the fact that they were a cause of the disorder of retaliatory violence. Murray also felt that by suppressing sorcery he was freeing indigenous Papuans from that genuine fear which he felt blighted their whole existence:

10 See especially Gray (1999:56) and Hudson (1974:14), who maintained that Murray was caught by 'the three prongs of social conditions, the administrative and anthropological theories of his time, and his own preconceptions about the objects of administration'.

11 In spreading Anglo-Australian concepts of law and order, Murray did note that some of the older Papuans might regret 'the more stirring days of their youth'. As the administration had stopped all the excitement attached to raiding etc., the colonisers had to do their best to 'convert the disappointed raider into a more or less industrious husbandman' (Murray 1929a:20). 
Sorcery ... is very real to the native, who in many parts of the Territory, is hardly free for one moment from the fear of sorcery, from the cradle to the grave, throughout the whole of his demon haunted life. (Murray 1938:9)

Despite having fought in the Boer War, he maintained that he had never realised what fear 'really meant' until he saw it in the eyes of an indigenous Papuan terrified by the potential wrath of a sorcerer (Murray 1929b:14). Accordingly, there was a very humane dimension to Murray's determination to stamp out sorcery, rather than simply an unreflective opposition.

Indeed, Murray was not above using sorcery to further public policy ends. In the wake of a smallpox scare in 1912-1913, Murray let it be known that a very dangerous and powerful sorcerer had conjured up a very bad sickness. But, although the sorcerer was strong the government was stronger, and when he saw the mark from the government - that is, the smallpox injection - he would realise that he was powerless and would 'retire foiled and baffled'. The smallpox scar became hugely popular, not only medically, but socially, and to be without the mark 'was to confess one's self the veriest outsider' (Lattas 1996:153). Nonetheless, although Murray's administration aimed to implement policies which the colonisers perceived as in the best interests of indigenous Papuans, the methods remained essentially those of control, law and order, and petty discipline. Hank Nelson (1982:20) suggests that the tragedy of Murray's career was that he served for so long that policies which had been progressive at the beginning of his tenure had become discriminatory and damaging by the end of it.

As for the anthropologists, on one hand there was the view of the Papuan Government Anthropologist F.E. Williams that the enforcement of the law against sorcery had done much to check its most harmful manifestations. He argued that where there was corroborative evidence of sorcery practice or a guilty plea, punishment enough to 'teach him a lesson, to make it psychologically impossible for him to pose as a sorcerer again' (Williams 1935:25). In stark contrast, New Zealand social anthropologist Reo Fortune argued against the ineffectual nature of the legal-administrative approach in a letter to Murray in 1928:

haphazard hitting a certain practice while the beliefs behind are strong and undisturbed ... can only terrorise practices into greater and greater secrecy and underhandedness. It is not a worthy thing. (Gray 1999:61)

As the Sorcery Act was introduced towards the end of the colonial era, but at a time when PNG was still subject to the Commonwealth Department of External Territories, it might reasonably have been assumed that it was a prime example of the colonisers using the blunt instrument of legislation to deal with a complex 
social issue. However, the Sorcery Bill was in fact introduced in the PNG House of Assembly by one of the Papua New Guinean members: on the last day of the June 1970 meeting of the assembly, Sir Paul Lapun, then member of parliament for South Bougainville, presented a Sorcery Bill, based on his stated belief that 'the people of this country, know that sorcery does occur' (Johnson 1983:19).

The ensuing Sorcery Act basically reiterated the earlier colonial sanctions, making it an offence to directly or indirectly pretend to be, hold one's self out to be, or profess to be a sorcerer who sought to do harm. However, it deliberately hedged its bets on the reality or otherwise of evil sorcery, so that Section 5 of the Act provides that:

Even though this Act may speak as if powers of sorcery really exist (which is necessary if the law is to deal adequately with all the legal problems of sorcery and the traditional belief in the powers of sorcerers), nevertheless nothing in this Act recognizes the existence or effectiveness of powers of sorcery in any factual sense except only for the purpose of, and of proceedings under or by virtue of, this Act, or denies the existence or effectiveness of such powers.

This ambivalence was reinforced by the Act's evidentiary provisions. Once it had been proved that a person had committed an act of sorcery, it was immaterial that that act was actually incapable of causing the result intended, if the sorcerer, the intended victim, or anyone else who was meant to be influenced by the sorcerer's act believed that it was capable of producing that result. ${ }^{12}$

\section{Conclusion}

In its 1978 paper on sorcery among the Tolai, the PNG Law Reform Commission concluded that although sorcery could not be abolished, it might nonetheless be necessary for the law to be 'tough on evil sorcery' to reduce the incidence of its practice (LRCPNG 1978:16). While the Sorcery Act obviously failed to do so, an examination of its colonial roots suggests that this may be in part due to the fact that it can be characterised as 'weak' or 'state' legal pluralism, as opposed to 'strong' or 'deep' legal pluralism.

The delineation between these two concepts has been the subject of considerable debate for the past three decades, ${ }^{13}$ but Miranda Forsyth has summarised the divide by noting that strong legal pluralism involves 'the coexistence of legal orders with different sources of authority', whereas with weak legal pluralism

12 Reading together Section 18 and Schedule 2 to the Act.

13 For a detailed discussion see Benda-Beckmann (2002). 
there are 'two or more bodies of norms that have the same source of authority' (Forsyth 2009:43). The centrality of the practice of sorcery to traditional Papua New Guinean society was recognised by colonial administrators; had they regarded it as harmless, although offensive to their own societal norms, they most likely would have let it be. However, the violence attendant upon these practices impinged upon public order and moved them squarely into the realm of the introduced criminal law with its prescribed processes and penalties. Thus, rather than create some means of recognising the law-nature of sorcery, the ubiquity of belief in it was acknowledged in the sentencing process, in that sentences were relatively light for murders which arose from the sincere belief that the victim was a sorcerer. ${ }^{14}$

It is arguable that this weak legal pluralism contributed to what would appear to be the ultimate inadequacy of the Sorcery Act - on one hand it gave belief in sorcery normative status by enshrining it in legislation aimed at preventing and punishing 'evil practices of sorcery and other similar evil practices'; on the other hand it operated on the assumption that sorcery could effectively be dealt with by Western processes of law enforcement, rules of evidence and judicial decision-making. One Australian judge concluded that this very ambiguity meant that many indigenous Papua New Guineans felt that where sorcery allegations arose they had to take the law into their own hands, and then accept the Western legal consequences. ${ }^{15}$

In writing on 'Sorcery and Magic', American anthropologist Leonard Glick (1973) was unfortunately very prescient when he suggested that more, rather than fewer, sorcery accusations would be part of social life in PNG, and argued that every effort should be made to understand them, in their own social contexts, as manifestations of conflict. Although legal decision-makers did not doubt the reality of sorcery to indigenous Papua New Guineans, they in no way shared the faith in its existence or its efficacy. Magistrates and prosecutors applied the adopted Criminal Code, scrupulously adhering to the principles of evidence. In doing so, they failed to realise that one of the key ways in which they could have spoken a common language in relying upon those principles was through an appreciation of the fact that the witchcraft trial had goaded the common law into rational modernity, centred on provable evidence.

In adopting effectively a weak pluralist approach to sorcery by assuming that its suppression could be brought about by the imported processes of the criminal law, the failure of the Sorcery Act as a deterrent perhaps became inevitable

14 F.P. Winter, William MacGregor's chief judicial officer, noted that whereas it would be 'pernicious' to allow customary motives for murder to influence a verdict, it was 'perfectly equitable to regard it as a sufficient palliation to warrant a commutation of the sentence' (Legge 1956:71).

15 Justice David Selby of the NSW Supreme Court spent 6 months as acting judge of the Supreme Court of Papua New Guinea in 1961-1962, hearing cases which often involved sorcery and murder (Selby 1964:29). 
as the social stresses identified by Glick intensified in contemporary PNG. If, perhaps, Hubert Murray's sympathies had occasionally allowed for the insights of anthropological discoveries to outweigh the demands of public order, the colonial regime may have crafted a stronger legal pluralism, which could have made a more effective and nuanced legal response to the current scourge of sorcery-related crime.

\section{References}

Angelo, A.H., H. Kirifi and A. Fong Toy 1989. Law and Tokelau. Pacific Studies 12(3):29-52.

Blaut, J.M. 1989. Colonialism and the Rise of Capitalism. Science \& Society 53(3):260-96.

Davies, O. 1999. Witchcraft: The Spell That Didn't Break. History Today 49(8):7-16.

Donovan, J.M. 2008. Legal Anthropology: An Introduction. Lanham, Maryland: Altamira Press.

Elkin, A.P. 1940. The Place of Sir Hubert Murray in Native Administration. The Australian Quarterly 12(3):23-35.

Forsyth, M. 2009. A Bird That flies with Two Wings: Kastom and State Justice Systems in Vanuatu. Canberra: ANU E Press.

Gaskill, M. 2005. Witchfinders: A Seventeenth Century English Tragedy. Cambridge, MA: Harvard University Press.

Gaskill, M. 2008. Witchcraft and Evidence in Early Modern England. Past and Present 198(1):33-70.

Glick, L. 1973. Sorcery and Magic. In I. Hogbin (ed.) Anthropology in Papua New Guinea: Readings from the Encyclopaedia of Papua and New Guinea. Melbourne: Melbourne University Press, 182-6.

Gray, G. 1999. 'Being Honest to My Science': Reo Fortune and JHP Murray, 1927-1930. The Australian Journal of Anthropology 10(1):56-76.

Hoebel, E.A. 1946. Law and Anthropology. Virginia Law Review 32(4):835-54.

Hoffer, P.C. 1997. The Salem Witchcraft Trials: A Legal History. Lawrence, Kansas: University Press of Kansas.

Hudson, W.J. (ed.) 1974. New Guinea Empire: Australia's Colonial Experience. Melbourne: Cassell. 
Talking it Through

Johnson, L.W. 1983. Colonial Sunset: Australia and Papua New Guinea 1970-74. St Lucia: University of Queensland Press.

Joyce, R.B. 1971. Sir William MacGregor. Melbourne: Oxford University Press.

Larner, C. 2002. The Crime of Witchcraft in Early Modern Europe. In D. Oldridge (ed.) The Witchcraft Reader. London: Routledge, 205-12.

Lattas, A. 1996. Humanitarianism and Australian Nationalism in Colonial Papua: Hubert Murray and the Project of Caring for the Self of the Coloniser and the Colonised. Australian Journal of Anthropology 7(2):141-65.

Legge, J. 1956. Australian Colonial Policy: A Survey of Native Administration and European Development in Papua. Sydney: Angus and Robertson.

LRCPNG (Law Reform Commission of Papua New Guinea) 1978. Sorcery among the Tolai People. Occasional Paper No. 8. Waigani: LRCPNG.

Murray, J.H. 1929a. Native Administration in Papua. Port Moresby: Government Printer.

Murray, J.H. 1929b. The Response of the Natives of Papua to Western Civilization. Port Moresby: Government Printer.

Murray, J.H. 1938. The Machinery of Indirect Rule in Papua. Port Moresby: Government Printer.

Nelson, H. 1982. Taim Bilong Masta: The Australian Involvement with Papua New Guinea. Sydney: Australian Broadcasting Commission.

Selby, D. 1964. Itambu! Sydney: Angus and Robertson.

Sinclair, J. 2009. Gavamani: The Magisterial Service of British New Guinea. Adelaide: Crawford House Press.

Thomas, K. 2004. The Relevance of Social Anthropology to the Historical Study of English Witchcraft. In M. Douglas (ed.) Witchcraft Confessions and Accusations. London: Routledge, 47-79.

Timmons, S. 2006. Witchcraft and Rebellion in Late Seventeenth Century Devon. Journal of Early Modern History 10(4):297-330.

Trevor-Roper, H.R. 1967. The European Witch-Craze of the Sixteenth and Seventeenth Centuries. Harmondsworth: Penguin.

von Benda-Beckmann, F. 2002. Who's Afraid of Legal Pluralism? The Journal of Legal Pluralism and Unofficial Law 47:37-82. 
Williams, F.E. 1935. The Blending of Cultures: An Essay on the Aims of Native Education. Port Moresby: Government Printer.

Wright, D.P. 2009. Inventing God's law: How the Covenant Code of the Bible Used and Revised the Laws of Hammurabi. Oxford: Oxford University Press. 
This text is taken from Talking it Through: Responses to Sorcery and Witchcraft Beliefs and Practices in Melanesia, edited by Miranda Forsyth and Richard Eves, published 2015 by ANU Press, The Australian National University, Canberra, Australia. 